\title{
On the Reliefs of Eternity and Presence in the Two Kinds of Merit-transference in 'Ōsō' and 'Gensō'
}

\section{Myōhō Igarashi}

In order that the sense of absolute security may be provided in the religion, there must exist the reliefs of eternity and presence in it. The reliefs of eternity and presence are presented in the most high degree in the thought of the two kinds of Merit-transference in 'Ōsō' and 'Gensō' of the Pure Land teachings.

The Merit-transference (parin̄āma) in 'Ōsō' is generally to tranfer one's merits of practices to other people in the phase of going forward to the Pure Land where Amitābha Buddha exists. And the Merif-transference in 'Gensō' is to transfer one's merits of the Pure Land to the others in the phase of returning. to this mundane world to save sentient beings.

These two kinds of Merit-transference have the origin in Aparimitãyus-sūtra (Sukhāvatī-vyūha), and are seen as the first developed thought in "Jōdoron" (Sukhāvatī-vyūhopadeśa) by Vasubandhu (born in the fifth century), and then are shown with the name of 'Ōsō' and 'Gensō' and with the detailed account for the two Merit-transferences in 'Ōjyōronchū' by Donran (T'an-luan, 476542), and they in the end develope into the principle of the complete construction of relief on the religious thoughts of Shinran (1173-1262).

In this treatise, I will deal with (I) the historical developement of the thoughts about the two kinds of Merit-transference in putting its points on Donran and Shinran, (II) the religious significances of the two Merit-transferences in putting emphasis on Donran, (III) the relation of the two Merit-transferences and the reliefs of eternity and presence in Shinran.

(I) It is Donran who used first the names of 'Ōsō' and 'Gensō' and described the detailed account for the two Merit-transferences. But he succeeded the original thought of the two Merit-transferences from Vasubandhu. 
(34) On the Reliefs of Eternity and Presence in 'Ōsō' and 'Gensō' (M, Igarashi)

In 'Jōdoron,' Vasubandhu described the fivefold practices (Worship, Invoking of the Name, Vowing of the rebirth, Meditation, Merit-transference) to rebirth in the Pure Land and set forth the thought of the two Gates of entering gate and leaving gate in the Pure Land. Using the thought of the two Gates of entering and leaving which have shown by Vasubandhu, Donran in 'Ōjyōronchū' explained the meaning of the Merit-transference, dividing it into two part 'Ōsō' and 'Gensō.'

In 'Ōjyōronchū,' the Merit-transference in 'Ōsō' is what one transfers his own practicing merits for the sake of all beings and prays to be born together in Amitābha's Pure Land, and the Merit-transference in 'Gensō' is what, after having been in the Pure Land and having realized the expendency to save other beings by the deep meditation and contemplation, one returns to this sentient beings' world hovering between life and death as if roaming in a dense forest, and one leads them together to follow the Way to Buddhahood and then all the sentient beings are relieved from the suffering world.

And also, it is shown that three Vows (the Eleventh Vows assuring the unfailing attainment of Nirvana, the Eighteenth Vow pleading the true faith, and the Twenty-second Vow showing the Merit-transference in the phase of returning) may be condensed of the Fourty-eight Original Vows which Amitābha Buddha had vowed and fulfilled to save all the beings.

Shinran inherited these two Merit-transferences and these three Vows, and added the Seventeenth Vow (which Amitäbha's name should be praised by all Buddhas) to them, and he formed the religious construction combining the two Merit-transferences with the four Vows. He probably succeeded the Seventeenth Vow from Hōnen (1133-1212), his reverend teacher. It is because that Hōnen regarded the Seventeenth Vow as important and quoted it in his work 'Sanbukyōtaii.' In Shinran's main work 'Kyōgyōshinshō,' he set the two kinds of Merit-transference in 'Ōsō' and 'Gensō' in the base of his religious construction of relief, and mentioned that there are true Teaching, Practice, and Faith in the phase of 'Ōsō,' and true Enlightenment in the two phases of 'Ōsō' and 'Gensō.'

In addition to it, he related that the Merit-transference in 'Ōsō' depends upon the Seventeenth Vow, the Eighteenth Vow, and the Eleventh Vow, and 
On the Reliefs of Eternity and Presence in 'Ōsō' and 'Gensō' (M. Igarashi)

the Merit-transference in 'Gensō' depends upon the Twenty-second Vow. And yet, as showing 'Genso,' he sometimes used the sentences in 'Jōdoron' and 'Ōjyōronchū' instead of the sentence in the Twenty-second Vow. It is because that the sentence in the Twenty-second Vow is not necessarily expressed clearly the state of the Merit-transference in 'Gensō' and these sentences in 'Jödoron' and 'Ōjyōronchū' replenish the insufficiency of the Twenty-second Vow.

Then, there is a most distinctive difference between Donran and Shinran. The difference is that Donran accepted the two Merit-transferences as man's effectual activities resulting from the five practices to rebirth in the Pure Land, but Shinran accepted these as Amitābha-buddha's affectionate activities resulting from the practices for an extremely long time to save all beings as Dharmākara before his enlightenment, and each man is able to carry out the two Merit-transferences only by believing the Power of Amitābha Buddha.

(II) In putting emphasis on the thoughts of Donran, I can indicate the following points concerning the religious significances on the two kinds of Merittransference. At first, the Amitābha's Pure Land is not a negative place of stillness but a very active place. The aspects of benefiting oneself and benefiting others are fully completed in the virtues of the Amitābha Buddha, while the practitioners get the virtues of Amitābha, and realize the two Merit-transferences by themself. These two phases are the most complete developement of the Way of Bodhisattva-hood in Mahayāna Buddhism.

Secondly, the two Merit-transferences are concrete realization of Amitābhabuddha's Vows, and come from the Infinite Compassion (maitrī and karuñā) of Amitābha. And they are shown with the words of the 'Power in fulfilling of the Original Vows' (pūrva-praniidhāna-vásāt) in 'Ōjyōronchū.'

And in the end, the principle of the 'Power in fulfilling of the Original Vows' is explained in the relation of 'Dharmatā' and the 'Provisional Dharma-kāya' in two bodies of 'Buddha' or 'Tathāgata' in 'Ōjyōronchū.' 'Dharmatā' is also expressed as 'Tathatä' and it is the real nature of the phenomenal world, and it is simultaneously ineffable, unmanifested, and non-substantial. The 'Provisional Dharma-kāya' is the corporealized form of 'Tathatā' or 'Dharmatā' and it manifests itself necessarily to help suffering beings, 'Dharmatā' and the 'Provisional 
(36) On the Reliefs of Eternity and Presence in 'Ōsō' and 'Gensō' (M. Igarashi)

Dharma-kāya' are in the relation of different and yet not to be separated, and both of them depend upon each other. And the Power of the Original Vows is the more corporealized one from the 'Provisional Dharma-kãya' as the expediency to relieve all beings.

(III) Shinran received subjectively the two Merit-transferences, and it is 'Hearing' that could show concretely the condition of his subjective receiving. 'Hearing' in his religious thoughts, is to hear, to be convinced the deep reason why Dharmākara had to vow his Original Vows and accomplish them. In the chapter III 'Faith' in 'Kyōgyōshinshō,' there is the following sentence.

Now the Sütra says that 'Hearing' is that sentient beings hear why Amitābhabuddha's Vows had to be vowed, what was the cause and what the effect, and no doubt is there.

What, in fact, is this reason of Dharmākara's Vows? Dharmākara vowed his Original Vows, and his Vows are the concrete of the Amitäbha's Infinite Compassions. They are necessary facts to relieve the multitudes who are not able to be rescued forever from the sea of sufferings.

When one hears the reason and receives it deeply in his heart, one can understand the truth of the Original Vows and can entrust himself to the Power of Amitābha and then can get the life of absolute relief over this world.

Next, the two Merit-transferences are the world of the Amitäbha's Power and take the form of the phase of infinite circular motion. It is the complete endlessness in a circumference. To this, before the age of Hōnen and Shinran, Japanese Pure Land teachings had become the symbol of the evasion from the reality by laying emphasis only on going to Amitābha's Pure Land under the motto of 'Getting off this Impure Land and Seeking Rebirth in the Pure Land.' It is the incomplete endlessness in a straight line. One feels the absolute easiness in the former and does not in the latter.

Now, if one thinks the circle of two Merit-transferences as magnifying endlessness, it will become the greatest phase of the Wonderful Virtues and the Innumerable Compassions of Amitābha, and if one thinks that it is to be condensed endlessly, it will become the existential presentation.

The phase of the Wonderful Virtues and the Innumerable Compassions is 
On the Reliefs of Eternity and Presence in 'Ōsō' and 'Gensō' (M. Igarashi) also the world that one is able to feel the Buddha-nature (buddhatã) in everything. There are the following sentences in 'Yuishinshōmon-i' by Shinran.

'Tathatās' are full in all innumerable world of sentient beings, they are in all the heart of multitudinous beings in the suffering ocean. It is shown in Sütra that all of the grasses, the trees and the lands will become 'Buddhas.' Tathatās let all beings. receive Amitābha's Original Vows, so that each 'receiving' in the beings has the Nature of Buddha, and the Nature of Buddha is the Nature of Dharma (dharmatã), This Nature of Dharma is itself the Substance of Dharma (dharma-kāya).

The Buddha of Reward-body (sambhoga-kāya) in reward for the Original Vows of Dharmākara manifests the innumerable bodies of Buddha and lets them emit the unhindered lights of wisdom in the innumerable world, and thus the Buddha is called by the name of the 'Buddha whose Light is Unhindered in the Ten Quarters.'

Understanding by these sentences that all things in this world are the appearances. of the Buddha of Infinite Light (Amitābha) and Unending Life (Amitāyus) and one's faith is established by the saving operation of the two Merit-transferences, we are able to have the absolute relief with great pleasures. By the existential presentation on one side, one is awaken himself from being bound with his selfish action and he gets the consciousness of true freedom in the Power of Amitābha. And it is 'Jinenhōni' that combines and harmonizes the infinite world of Amitābha's Virtues and the existential presentation. 'Jinen' in 'Jinenhōni' is the' meaning of things being as they are, and that is to receive the operation of the cause and the effect in everything as the spontaneous operation of the Power of Amitābha. 'Hōni' means the 'Dharmas' being as they are, and also. expresses the operation of the Amitābha's Power. 'Jinenhōni' shows the inevitability of everything moving with the Amitābha's Power of Virtues and that one shouldn't be swayed at his selfish indiscretions.

By these, one gains the relief in eternity by riding on the Power of Amitābha, the two Merit-transferences, and the relief in existential presentation of being: freed from this mundane world and also the relief in making up his mind to accept stately the consequence of his actions. And then one is positively able to take the part vividly in this world and to find much amusement of the Amitābha's Power in everything. (September 30. 1977) 